\title{
KINERJA LEMBAGA KEUANGAN MIKRO SYARIAH DALAM MENINGKATKAN KESEJAHTERAAN SANTRI (STUDI PONDOK PESANTREN SALARY ABDUSSALAM)
}

\section{ISLAMIC MICRO FINANCE INSTITUTIONS PERFORMANCE IN IMPROVING THE WELFARE OF SANTRI (STUDY OF PONDOK PESANTREN SALARY ABDUSSALAM)}

\author{
Hasanatul ahwal1a; Adi Rahmanur Ibnu² \\ Program Studi Ekonomi Syariah Fakultas Ekonomi Islam Universitas Djuanda, Jl. Tol Ciawi \\ No. 1, Kotak Pos 35 Bogor 16720. \\ Program Studi Perbankan Syariah Fakultas Ekonomi Islam Universitas Djuanda, Jl. Tol \\ Ciawi No. 1, Kotak Pos 35 Bogor 16720.
}

\begin{abstract}
ABSTRAK
Penelitian bertujuan untuk mengetahui secara lebih mendalam terkait kinerja BMT Barokah Abdussalam yang turut andil dalam mendukung kesejahteraan santri ditinjau dari layanan dan pemanfaatan produk serta desain produk pada BMT. Sampel yang digunakan ialah santri yang berada di pondok pesantren berdasarkan ketentuan metode pengambilan sampel Issac and Michael dengan menggunakan teknik Purposive Random Sampling dengan menyebarkan kuesioner kepada 205 santri. Adapun analisis data yang digunakan ialah Structural Equation Modelling (SEM). Hasil dalam penelitian ini menunjukkan bahwa kinerja memiliki pengaruh positif terhadap kesejahteraan santri di pondok. Kinerja memiliki pengaruh positif terhadap produk BMT. Produk memiliki pengaruh positif kesejahteraan santri. Hasil tersebut juga didukung oleh perolehan nilai antar konstruk yang memiliki nilai yang positif dan signifikan.
\end{abstract}

Kata kunci: Kinerja LKMS, Produk, Kesejahteraan, Pondok pesantren

\begin{abstract}
The study aimed to find out more in depth the performance of BMT Barokah Abdussalam who contributed in supporting the welfare of santris in terms of services and product utilization and product design at BMT. The sample used was the santris who were life at the boarding school Abdussalam based on the provisions of the Issac and Michael sampling method using Purposive Random Sampling technique by distributing questionnaires to 205 santris. The data analysis used is Structural Equation Modeling (SEM). The results in this study indicate that performance has a positive influence on the welfare of students in the cottage. Performance has a positive influence on BMT products. Products have a positive influence on students' welfare. These results are also supported by the acquisition of values between constructs that have positive and significant value.
\end{abstract}

Keywords: Performance of LKMS, Products, Welfare, Islamic Boarding Schools 
Hasanatulahwal. 2019. Kinerja Lembaga Keuangan Mikro Syariah Dalam Meningkatkan Kesejahetraan Santri (Studi Pondok Pesantren Salary Abdussalam). Jurnal Syarikah 5 (1): 31-39.

\section{PENDAHULUAN}

Kesejahteraan merupakan salah satu komponen yang menjadi tolok ukur paling utama selain komponen pembangunan untuk melihat tingkat kelayakan dari kehidupan yang ada pada lapisan masyarakat. Ukuran tersebut dapat dilihat dari tingkat kesehatan, perekonomian dan komponen lain yang dimiliki oleh masyarakat, secara harfiah kesejahteraan dapat dilihat dari kelayakan dan materi yang dimiliki oleh masyarakat diukur melalui tingkat pertumbuhan ekonomi dan juga pendapatan mereka (Artana Yasa \& Arka, 2015: 63). Namun menurut Pratama dan Mandala (Widyastuti, 2012: 2) tingkat kesejahteraan, tidak hanya diukur berdasarkan materi saja, seperti halnya tingkat perekonomian masyarakat akan tetapi juga dapat diukur berdasarkan tingkat pendidikan dan kebahagiaan yang dirasakan oleh masyarakat. Berdasarkan data yang disajikan oleh BPS pada tahun 2017 tingkat kebahagiaan masyarakat Indonesia sebesar $70,69 \%$ pada skala 0 100 , angka ini mengalami peningkatan dari pada tahun 2014 lalu yakni sebesar $68,28 \%$ (BPS, 2017: 192).

Adapun indikator yang menjadi tolok ukur kesejahteraan masyarakat yang ditentukan oleh pemerintah meliputi: jumlah penduduk, gizi, kesehatan, pendidikan, tenaga kerja, konsumsi masyarakat, perumahan atau tempat tinggal juga mencakup lingkungan sekitar, tingkat kemiskinan dan indikator lain yang dinilai dapat mencerminkan kualitas hidup yang dimiliki masyarakat (BPS, 2016: 102), salah satunya ialah indikator kebahagiaan yang ditambahkan oleh BPS pada tahun 2017. \begin{tabular}{llr}
\multicolumn{1}{c}{ Salah } & satu upaya & dalam \\
meningkatkan & kesejahteraan & ialah \\
melakukan & pemberdayaan & kepada
\end{tabular} masyarakat, baik dalam hal sosial ataupun ekonomi yang memiliki banyak pengaruh dalam meningkatkan kesejahteraan masyarakat (Prabowo, 2015: 182).

Pendirian LKMS ialah untuk mewujudkan konsep Maqashid Syariah di tengah-tengah kehidupan masyarakat, sehingga falah yang juga menjadi salahsatu tujuan dasar ekonomi syariahpun dapat tercapai (R.A Y Prasetya \& S. Herianingrum, 2016: 253). LKMS dalam perkembangannya sebagai lembaga keuangan mikro non-bank mempunyai sepak terjang yang berperan penting dalam kehidupan masyarakat, salahsatunya dengan turut andil dalam meningkatkan Usaha Mikro Kecil Menengah (UMKM) masyarakat yang umumnya memiliki kendala dalam peningkatan modal usaha yang relatif kecil (Kara, 2013: 316), dengan menawarkan sistem dan juga produk yang diharapkan dapat membantu memudahkan masyarakat, dalam melakukan transakasi atau berwirausaha dalam skala kecil dan menengah yang umumnya masih sulit dilakukan oleh lembaga perbankan syariah (Alhifni \& Huda, 2015: 598 ; Mi'raj \& H.R, 2015: 858 ; Gina \& Effendi, 2015: 34 ).

Pemanfaatan LKMS tidak hanya diperuntukkan bagi masyarakat tertentu saja seperti halnya dalam mengembangkan UMKM, akan tetapi juga diperuntukkan untuk masyarakat umum, contohnya seperti memanfaatkan potensi LKMS terhadap lembaga Pondok Pesantren, Abidah (2013: 109). Hal tersebut dinilai akan berdampak bagi santri yang juga 
menjadi bagian dari masyarakat yang memiliki hak akan kesejahteraan sehingga dapat meningkat.

Ada beberapa Pondok Pesantren yang sudah bekerjasama dengan LKMS (BMT) salah satunya ialah kerjasama yang terjalin antara Pondok Pesantren Salafy Abdussalam dengan BMT Barokah Abdussalam,dengan adanya lembaga keuangan mikro syariah dalam lingkungan pesantren diharapkan dapat memberikan manfaat sekaligus menjadi wadah kreatifitas bagi para santri. Selain melihat dan merasakan secara langsung praktekpraktek aktifitas ekonomi yang sesuai syariah, lembaga keuangan mikro syariah juga dapat mendukung para santri dalam mengelola dan mengatur pola keuangan selama berada di pesantren.

\section{MATERI DAN METODE}

\section{KINERJA LKMS}

Menurut teori yang telah dipaparkan oleh Richard Schechner (1994: 30) kinerja merupakan sekumpulan aktifitas yang dikerjakan baik oleh individu ataupun kelompok orang untuk kepentingan individu atau kelompok lain, pendapat ini sejalan dengan pendapat yang dikemukakan oleh Colquitt \& dkk (2009: 37), dimana kinerja dipandang sebagai prestasi kerja yang terdiri dari kumpulan nilai-nilai yang turut andil dalam tercapainya tujuan suatu kelompok atau perusahaan baik dalam konteks baik ataupun buruk (Pramono, 2014: 116). Sedangan LKMS LKMS yang dalam hal ini BMT (Baitul Maal Wat Tamwil) secara umum disebut sebagai suatu lembaga unit keuangan ekonomi syariah yang cenderung melayani dan menawarkan produk syariah yang berbasis pada transaksi-transaksi mikro dari kecil sampai menengah (Kuncoro \& Husnurrosyidah, 2017: 65). Menurut Hertanto (Muttaqin, 2012: 37) menyatakan bahwa Baitul Maal merupakan sebuah lembaga yang secara fungsi merupakan lembaga penghimpun dana untuk disalurkan kembali kepada masyarakat dalam bentuk zakat, infaq juga shadaqah, Sedangkan Baitul Tamwil secara fungsi dapat diartikan sebagai lembaga yang dapat mengembangkan harta malalui sistem bagi hasil, margin dan lainnya. Ada beberapa indikator yang dipilih untuk dapat menggambarkan besaran kinerja yang ada di LKMS diantaranya adalah:

1. Margin pembiayaan murabahah

Margin merupakan sesuatu yang di peroleh dari selisih harga jual yang dikurangi dengan harga pokok pada saat transakasi yang dilakukan oleh kedua pihak yang didasarkan pada prinsip keadilan, (Fidyah, 2017: 21). Besaran margin juga mempunyai pengaruh yang positif dan signifikan terhadap minat nasabah dalam menggunakan produk murabahah. Sehingga dapat disimpulkan bahwa besaran margin dapat menigkatkan minat masyarakat dalam memanfaatkan jasa dan fasilitas yang ditawarkan oleh BMT (Wulandari 2017: 73). 2. Bagi hasil pembiayaan mudharabah

Pembiayaan mudharabah merupakan pembiayaan yang berisi transaksi antara mudharib (pengelola dana) dan shahibul maal (pemilik dana). Dengan adanya pembiayaan mudharabah ini bagi hasil diterapkan sebagai buah dari keuntungan yang diperoleh melalui usaha yang dilakukan oleh lembaga. Pada umumnya besaran basil ditentukan berdasarkan kesepakatan antara kedua pihak (AC, 2015: 32).

3. Waktu pemerosesan

Waktu pemrosesan merupakan salah satu indikator yang menentukan penjualan produk bagi lembaga, hal ini disebabkan karena pengaruh langsung dari waktu pemrosesan dengan efisiensi yang dirasakan oleh konsumen sehingga dapat memberikan kepuasan kepada para konsumen atau anggota. Efisiensi menurut Mardismo (2009: 
132) ialah proses operasional yang berkaitan erat dengan suatu produktifitas (Sumenge, 2013: 76).

4. Kemudahan pelayanan

Pelayanan merupakan indikator penentu yang dapat mempengaruhi calon konsumen dalam menentukan pembelian produk. Tersedianya pelayanan yang mudah akan membuat calon konsumen lebih percaya dan yakin untuk menggunakan jasa atau produk yang ditawarkan oleh lembaga. Bahkan Gilber dkk (2004) menyatakan bahwa kualitas layanan memiliki pengaruh terhadap kinerja keuangan suatu lembaga/perusahaan (Aryani \& Rosinta, 2010: 115), hal tesebut juga sejalan dengan hasil penelitian (Saidani \& Arifin, 2012: 21) yang mengemukakan bahwa kualitas layanan akan mempengaruhi kepuasan konsumen, sehingga akan menyebabkan loyalitas konsumen menjadi lebih baik.

5. Keaktifan anggota.

Anggota merupakan salah satu pilar dalam operasional BMT, partisipasi anggota dalam memanfaatkan produk yang ada di BMT menurut Yuliani dkk (2017: 111) anggota dapat mempengaruhi tingkat kinerja BMT menjadi lebih baik. Salah satu partisipasi yang dinilai dapat meningkatkan kinerja BMT ialah pemanfaatan produk simpanan yang dinilai dapat meningkatkan modal BMT.

\section{KESEJAHTERAAN}

Kesejahteraan masyarakat atau yang lebih dikenal dengan kesejahteraan sosial menurut Dwi Heru Sukoco (1995) merupakan pelaksanaan beberapa kegiatan yang terkait dengan kepentingan masyarakat yang berperan secara langsung untuk meningkatkan kesejahteraan masyarakat baik dalam peningkatan SDM maupun peningkatan kualitas hidup masyarakat (Luthfi, 2013: 4).

Bainus dkk (2015: 4) memaparkan ada tiga konsep untuk menggambarkan sebuah kesejahteraan, yaitu:
1. Kesejahteraan secara umum merupakan suatu keadaan yang memiliki keterkaitan dengan kebahagiaan dan kemakmuran.

2. Memandang kesejahteraan secara spritual dimana Islam mengharuskan landasan konsep kesejahteraan didasarkan kepada Al-Quran sehingga dapat mencapai falah.

3. Mengukur kesejahteraan dari kualitas hidup masyarakat baik secara materi ataupun non materi.

Berdasarkan konsep di atas ada beberapa indikator yang dipilih untuk dapat menggambarkan kesejahteraan yang ada di Pondok Pesantren diantaranya ialah:

1. Kesehatan

WHO (2008) menyatakan kesehatan merupakan pencerminan dari segi fisikmaupun mental yang tidak mengalami kondisi sakit atau lemah (Chamidah, 2010: 64).

2. Pendidikan

Menurut (BPS, 2003) pendidikan merupakan modal atau investasi yang dapat meningkatkan kesejahteraan seseorang pada masa yang akan datang (Maulidah \& Seojoto, 2015: 229).

3. Keamanan

Collins (2005) menyatakan bahwa keamanan merupakan wujud nyata dari adanya keadilan sosial dan terbentuknya kesejahteraan ekonomi, sedangkan menurut Critical Scurity Studies keamanan akan terbentuk apabila masyarakat dapat merasakan adanya rasa bebas dari rasa takut dan kemiskinan (Susetyo, 2008: 3).

4. Kebahagiaan

Menurut salah satu penggugah aliran psikologi positif yakni Slegman (2002) menyatakan bahwa kebahagiaan merupakan kompenen dari muatan emosi yang ada dalam suatu individu saat melakukan kegitatan yang bersifat positif (Anggoro \& Widhiarso, 2010: 177). 


\section{IPM}

IPM (Indeks Pembangunan Manusia) merupakan salah satu indikator penting mengukur pencapaian yang diperoleh terkait upaya dalam meningkatkan kualitas hidup masyarakat.

\section{PRODUK}

Menurut Philip Kotler \& Garry Amstrong (2001: 346) produk merupakan wujud dari sesuatu yang ingin dipasarkan oleh produsen terdiri dari barang atau jasa baik yang bersifat tangibel maupun intangibel hal ini juga sejalan dengan produk-produk yang ada di BMT, dimana produk tidak semata-mata hanya bersifat maaliyah akan tetapi juga berbentuk tabarru' (Alhifni \& Huda, 2015: 599).

Variasi produk menurut Deschamps (1999: 35) merupakan faktor yang sangat penting, menurutnya variasi produk termasuk salah satu cara untuk memberikan service yang maksimal kepada konsumen, dengan cara memberikan banyak pilihan sehingga konsumen berkesempatan untuk memilih produk yang paling sesuai dengan keinginannya, selain itu variasi produk BMT dapat diukur dengan melihat variasi produk yang sudah ditawarkan oleh pihak BMT dan menyesuaikannnya dengan kebutuhan lingkungan dan juga masyrakat sekitar (Luviana, 2014: 10). Ada beberapa produk yang dijadikan sebagai penggambaran untuk dapat mengukur kinerja LKMS diantaranya ialah produk simpanan syariah, simpanan pendidikan, simpanan hari raya, pembiayaan mudharabah, pembiayaan murabahah.

\section{PONDOK PESANTREN}

Berdasarkan UUD No. 55 tahun 2007 pasal 6 ayat 1 maka Pondok Pesantren merupakan sebuah lembaga yang menyelenggarakan pendidikannya dengan tujuan dapat mendidik dan mengajak para generasi bangsa untuk menanamkan keimanan dan juga ketaqwaan kepada sang maha pencipta yakni Allah SWT, selain itu tujuan pembentukan pondok pesantren juga untuk membentuk generasi yang berakhlaq, berilmu serta memiliki kemampuan dengan maksud agar generasi dapat membantu menciptakan masyarakat Islami dengan memanfaatkan kecakapan dan juga pengetahun-pengetahuan lainnya (Hamid, 2017: 46). Pondok Pesantren sangat erat kaitannya dengan santri, menurut Hidayat (2016: 387) Santri merupakan kata sebutan untuk orang yang baik dan nilai taat pada agama dan menjauhi larangannya. Adapun asal usul dari penggunaan kata santri dalam menggambarkan komunitas tersebut dapat didefinisikan berdasarkan dua pandangan, pertama: kata santri berasal dari bahasa Sanskerta yang artinya mengetahui akan huruf kedua: berasal dari kata Jawa "cantrik" yakni seseorang yang mengikuti langkah sang guru kemanapun melangkah baik pergi ke suatu tempat ataupun tinggal di suatu tempat dengan tujuan dapat memperoleh suatu ilmu dari sang guru.

\section{Metode dan Sumber Data}

Penelitian ini dilakukan di Pondok Pesantren Salafy Abdussalam untuk melihat pengaruh kinerja LKMS terhadap kesejahteraan santri dengan menggunakan metode modelpersamaan struktural (SEM/Structural Equation Modeling). Adapun jumlah sampel yang diambil ialah berdasarkan metode Issac and Michael, dimana besaran sampel ditentukan oleh besaran populasi dan besaran eror yang digunakan, dimana $\mathrm{N}=500$ serta $a=5 \%$ maka $\mathrm{n}=205$. Sedangkan jenis data yang digunakan ialah data primer dengan metode non-Probability sampling menggunakan teknik penyebaran kuesioner kepada responden.

Ada beberapa ketentuan dalam menentukan sampel:

1. Santri sudah memanfaatkan tabungan yang ada di LKMS

2. Santri dapat memahami dan memberi jawaban berdasarkan option yang sudah 
disediakan dalam penelitian ini, terkait dengan syarat kedua ini penulis memilih santri yang sudah dduk di bangku SMA karena dinilai sudah memahami dan dapat memberikan jawaban yang objektif.

\section{Metode Analisis Data}

Adapun metode yang digunakan dalam menganalisis data ialah metode skala likert yang bertujuan untuk menganalisis perolehan kuesioner dari sebaran jawaban yang diperoleh dari responden, yaitu skala yang dapat digunakan untuk menilai sikap, kesetujuan atau ketidaksetujuan seseorang terhadap berbagai pertanyaan yang berkaitan dengan obyek tertentu (Hermawan, 2005: 132) dimulai dari poin 1 (satu) sangat tidak setuju sampai dengan poin 5 (lima) sangat setuju.

Tahap dalam pengujian SEM antara lain ialah: spesifikasi model, identifikasi kemudian uji model dan signifikasi berdasarkan nilai Chi-square, Goodness of fit index (GOF), adjusted goodness of fit index (AGFI), roat mean residual (RMSR). Uji signifikasi dapat dilihat dari perbandingan antara nilai t hitung /Cr dengan batas nilai kritisnya berdasarkan persamaan $a=5 \%$. Jika nilai $\mathrm{Cr} \geq$ nilai kritisnya maka signifikan, namun sebaliknya jika nilai $\mathrm{Cr} \leq$ nilai kritisnya maka tidak signifikan (Hafidloh, 2015:10).

\section{HASIL DAN PEMBAHASAN}

\section{Analisis Deskriptif Responden}

Deskriptif responden menjelaskan pertanyaan yang diajukan mengenai informasi jenis kelamin, usia, tingkat pendidikan, masa pesantren, produk yang dimiliki atau dimanfaatkan responden. Jumlah responden dari penelitian ini adalah 205 santri yang berada di Pondok Pesantren Abdussalam, selanjutnya penulis akan menjelaskan mengenai karakteristik responden dari pembahasan sebagai berikut:
Berdasarkan 205 kuesioner yang disebarkan pada responden, semua santri yang mengisi kuesioner ini adalah laki-laki dengan jumlah 125 orang dan perempuan dengan jumlah 80 orang dengan usia 15-20 tahun sebanyak 160 santri, sedangkan responden dengan usia 21-25 sebanyak 45 santri. Adapun latar belakang pendidikan responden rata-rata masih duduk di Sekolah Menengah Atas (SMA) sebanyak 155 santri, dan santri yang sudah lulus sekolah sebanyak 45 orang.

Berdasarkan 205 kuesioner yang disebarkan, hasil yang diperoleh, masa pesantren didominasi santri yang memiliki masa pesantren 1 tahun sebanyak 35 orang, 2 tahun 36 orang, 3 tahun 26 orang, 4 tahun 27 orang, 5 tahun 25 orang, 6 tahun 28 orang, 7 tahun 21 orang dan 8 tahun 7 orang santri. Berdasarkan 205 kuesioner yang disebarkan, hasil yang diperoleh adalah santri atau responden yang terdiri dari produk wadiah sebanyak 108 santri, pendidikan 73 santri, deposito 1 tahun sebanyak 10 orang dan simpanan hari raya sebanyak 14 orang santri.

\section{Uji Validitas dan Reliabilitas}

Pengujian validitas dan reliabilitas dilakukan untuk mengetahui ketepatan setiap pertanyaan yang ada didalam kuesioner, sedangkan pengujian reliabilitas bertujuan untuk mengetahui sejauh mana hasil suatu pengukuran dapat dipercaya. Adapun tinggi atau rendahnya reliabilitas dapat dilihat dari koefisien korelasi antara skor pada dua tes pararel yang dikenakan pada sekelompok individu yang menjadi sampel. Menurut putra dkk (2014: 178). Dasar pengambilan keputusan dalam metode ini adalah jika alfa cronbach's $<0,60$ maka konstruk tersebut dikategorikan kurang andal-cukup andal, dan sebaliknya jika alfa cronbach's >0,60 maka konstruk dapat dikategorikan andal-sangat andal. Berikut adalah hasil uji reliabilitas dan 
validitas yang dihasilkan dalam penelitian ini ialah sebagai berikut:

Tabel 1

Uji Validitas dan Reliablitas

\begin{tabular}{l|l|l}
\hline Indikator & $\begin{array}{l}\text { Cronbach's } \\
\text { Alpha }\end{array}$ & $\begin{array}{l}\text { Corrected Item- } \\
\text { Total Correlation }\end{array}$ \\
\hline KL1 &, 685 &, 307 \\
KL2 &, 682 &, 216 \\
KL3 &, 674 &, 372 \\
KL4 &, 676 &, 354 \\
KL5 &, 686 &, 277 \\
PL1 &, 687 &, 268 \\
PL2 &, 689 &, 252 \\
PL3 &, 698 &, 184 \\
PL4 &, 673 &, 278 \\
PL5 &, 673 &, 377 \\
KS1 &, 683 &, 305 \\
KS2 &, 680 &, 334 \\
KS3 &, 688 &, 287 \\
KS4 &, 685 &, 336 \\
KS5 &, 680 &, 293 \\
\hline Total & $\mathbf{, 7 0 6}$ & \\
\hline
\end{tabular}

Sumber: Data kuesioner diolah, 2018

Keterangan

KL1: Margin pembiayaan murabahah

KL2: Margin pembiayaan mudharabah

KL3: Waktu pemerosesan

KL4: Kemudahan pelayanan

KL5: Keaktifan anggota

PL1: Simpanan syariah

PL2: Simpanan pendidikan

PL3: Simpanan hari raya

PL4: Pembiayaan mudharabah

PL5: Pembiayaan murabahah

KS1: Kesehatan

KS2: Pendidikan

KS3: Keamanan

KS4: Kebahagiaan

KS5: IPM

Tabel di atas menunjukkan bahwa nilai perolehan alfa cronbach's yang dimiliki oleh setiap indikator ialah $\geq 0.60$ walaupun secara keseluruhan nilai alfa cronbach's $0.702 \geq$ dari 0.60 yang berarti konstruk ini masuk dalam kategori andal (Sugiono, 2015: 267). Sedangkan untuk melihat validitas dari masing-masing pertanyaan dengan corrected item-total correlation harus lebih besar atau sama dengan nilai $r$ tabel. Oleh karena itu, instrumen penelitian ini dinyatakan valid apabila hasil uji $\geq$ dari 0.1,72 ( $\mathrm{r}$ tabel), batasan tersebut diperoleh berdasarkan jumlah populasi yang ada pada responden. Hasil tabel di atas menunjukkan bahwa pernyataan yang digunakan untuk menggambarkan keseluruhan indikator yang ada tergolong valid dan dapat menggambarkan data yang dibutuhkan untuk mengetahui kinerja LKMS dalam meningkatkan kesejahteraan santri, ditunjukkan oleh perolehan nilai rata-rata Corrected Item-Total Correlation $\geq 1,72$.

Analisis dan Uji SEM

1. Menggunakan asumsi Assesment of normality sebagai dasar estimasi Maximum likelihood

2. Melihat hubungan antara konstruk (independen-dependen)

Berdasarkan asumsi tersebut berikut merupakan perolehan nilai maximum likelihood:

Tabel 2

Evaluasi Goodness of fit model

\begin{tabular}{|c|c|c|c|c|}
\hline \multicolumn{5}{|c|}{ No Goodness of Fit Model Cut off Keterangan } \\
\hline$(1)$ & $(2)$ & & 3) & 4) \\
\hline 1 & $\begin{array}{l}\text { Chi-Square } \\
\text { value }\end{array}$ & p- & $\begin{array}{l}229.639 \\
P= \\
(0.000)\end{array}$ & Marginal Fit \\
\hline 2 & RMSEA & & 0.09 & Good Fit \\
\hline 3 & RMR & & 0.49 & Good Fit \\
\hline 4 & NFI & & 0.42 & Good Fit \\
\hline 5 & CFI & & 0.51 & Good Fit \\
\hline 6 & IFI & & 0.61 & Good Fit \\
\hline 7 & RFI & & 0.41 & Good Fit \\
\hline 8 & Hoetler & & 98 & Good Fit \\
\hline 9 & GFI & & 0.89 & Marginal Fit \\
\hline 10 & AGFI & & 0.81 & Marginal Fit \\
\hline
\end{tabular}

Sumber: Data kuesioner diolah, 2018

Tabel di atas menunjukkan bahwa rata-rata variabel memiliki tingkat kecocokan, hanya 3 variabel yang memiliki nilai marginal, hal tersebut juga didukung oleh perolehana nilai degree of freedom (89) yang bernilai positif, sehingga dapat disimpulkan bahwa model 
SEM sudah tergolong fit. Berdasarkan perolehan di atas maka peneliti merumuskan hipotesis sebagai berikut:

$\mathrm{H}_{0}$ : Kinerja BMT tidak memberikan pengaruh terhadap peningkatan kesejahteraan santri.

$\mathrm{H}_{\mathrm{a}}$ : Kinerja BMT memberikan pengaruh terhadap peningkatan kesejahteraan santri.

Hipotesis kedua adalah:

$\mathrm{H}_{0}$ : Kinerja BMT tidak memberikan pengaruh terhadap peningkatan potensi pemanfaatan produk BMT pada santri.

$\mathrm{H}_{\mathrm{a}}$ : Kinerja BMT memberikan pengaruh terhadap peningkatan potensi pemanfaatan produk BMT pada santri.

Hipotesis ketiga:

$\mathrm{H}_{0}$ : Desain produk BMT tidak memberikan pengaruh terhadap peningkatan kesejahteraan santri.

$\mathrm{H}_{\mathrm{a}}$ : Desain produk BMT memberikan pengaruh terhadap peningkatan kesejahteraan santri.

Selanjutnya untuk mengukur ketepatan hipotesis di atas berdasarkan perolehan nilai hitung maximum likelihood dapat dijelaskan oleh tabel berikut ini.
Tabel 3

Pengujian Validitas dan Reliabelitas

\begin{tabular}{|c|c|c|c|c|c|}
\hline $\begin{array}{c}\text { Pengujian } \\
\text { Validitas \& } \\
\text { Reliabilitas }\end{array}$ & $\begin{array}{c}\text { Nilai } \\
\text { CR }\end{array}$ & $\begin{array}{c}\text { Nilai } \\
\text { Kritis }\end{array}$ & $\begin{array}{c}\text { Nilai } \\
\mathbf{P}\end{array}$ & Ket & $\begin{array}{c}\text { Hipotesi } \\
\mathbf{s}\end{array}$ \\
\hline KL1 & 2.472 & $\geq 1.72$ & 0.01 & $\begin{array}{l}\text { Valid } \\
\text { Reliabel }\end{array}$ & \multirow{5}{*}{$\begin{array}{c}\text { H1 data } \\
\text { menduk } \\
\text { ung CR } \\
(2.418) \\
\geq 1.72 \\
\text { P } 0.00 \\
\leq 0.05\end{array}$} \\
\hline KL2 & 2.634 & $\geq 1.72$ & 0.00 & $\begin{array}{l}\text { Valid } \\
\text { Reliabel }\end{array}$ & \\
\hline KL 3 & 3.293 & $\geq 1.72$ & 0.00 & $\begin{array}{l}\text { Valid } \\
\text { Reliabel }\end{array}$ & \\
\hline KL4 & 3.444 & $\geq 1.72$ & 0,00 & $\begin{array}{l}\text { Valid } \\
\text { Reliabel }\end{array}$ & \\
\hline KL5 & 3.444 & $\geq 1.72$ & 0,00 & $\begin{array}{l}\text { Valid } \\
\text { Reliabel }\end{array}$ & \\
\hline PL1 & 1.507 & $\geq 1.72$ & 0.13 & $\begin{array}{l}\text { Valid } \\
\text { Reliabel }\end{array}$ & \multirow{5}{*}{$\begin{array}{c}\text { H2 data } \\
\text { menduk } \\
\text { ung CR } \\
(2.612) \\
\geq 1.72 \\
\text { P } 0.02 \\
\leq 0.05\end{array}$} \\
\hline PL2 & 2.129 & $\geq 1.72$ & 0.02 & $\begin{array}{l}\text { Valid } \\
\text { Reliabel }\end{array}$ & \\
\hline PL3 & 3.351 & $\geq 1.72$ & 0.02 & $\begin{array}{l}\text { Valid } \\
\text { Reliabel }\end{array}$ & \\
\hline PL4 & 5.607 & $\geq 1.72$ & 0.02 & $\begin{array}{l}\text { Valid } \\
\text { Reliabel }\end{array}$ & \\
\hline PL5 & 5.607 & $\geq 1.72$ & 0.02 & $\begin{array}{l}\text { Valid } \\
\text { Reliabel }\end{array}$ & \\
\hline KS1 & 3.115 & $\geq 1.72$ & 0.00 & $\begin{array}{l}\text { Valid } \\
\text { Reliabel }\end{array}$ & \multirow{5}{*}{$\begin{array}{c}\text { H3 data } \\
\text { menduk } \\
\text { ung CR } \\
(2.418) \\
\geq 1.72 \\
\text { P } 0.00 \\
\leq 0.05\end{array}$} \\
\hline KS2 & 3.115 & $\geq 1.72$ & 0.00 & $\begin{array}{l}\text { Valid } \\
\text { Reliabel }\end{array}$ & \\
\hline KS3 & 3.024 & $\geq 1.72$ & 0.00 & $\begin{array}{l}\text { Valid } \\
\text { Reliabel }\end{array}$ & \\
\hline KS4 & 3.150 & $\geq 1.72$ & 0.00 & $\begin{array}{l}\text { Valid } \\
\text { Reliabel }\end{array}$ & \\
\hline KS5 & 3.366 & $\geq 1.72$ & 0.00 & $\begin{array}{l}\text { Valid } \\
\text { Reliabel }\end{array}$ & \\
\hline
\end{tabular}

Berdasarkan tabel 3 semua variabel tergolong valid dan reliabel, hal ini ditunjukkan oleh perolehan nilai $C R \geq 17,2$ (nilai kritis), serta nilai $P$ yang rata-rata $\leq 0,05$ (batas signifikasi) kecuali pada indikator PL1 (simpanan syariah) dengan skor $0,13 \geq 0,05$, dari skor tersebut dapat disimpulkan bahwa produk simpanan syariah (wadiah) tidak mempunyai pengaruh yang signifikan terhadap peningkatan kesejahteraan santri di Pondok Pesantren. Selanjutnya melihat hubungan masing-masing indikator akan digambarkan oleh tabel sebagai berikut: 
Tabel 4

Skor Hubungan Antar Indikator

\begin{tabular}{llllllllllll}
\hline & PL1 & PL2 & PL3 & PL4 & PL5 & KL1 & KL2 & KL3 & KL4 & KL5 \\
\hline PL & .034 & .056 & .080 & .263 & .279 & .009 & .010 & .025 & .026 & a \\
KS & .010 & .016 & .023 & .074 & .079 & .020 & .024 & .085 & .060 & .02 \\
KL & .002 & .003 & .005 & .015 & .016 & .041 & .049 & .117 & .122 & m.
\end{tabular}

Tabel 4 secara umum menggambarkan bahwa produk memiliki pengaruh terhadap tingkat kesejahteraan santri dan kinerja BMT Barokah Abdussalam. Berikut merupakan pengaruh dari masing-masing indikator. Ketika simpanan wadiah /syariah (PL1) mengalami peningkatan 0,34 maka kesejahteraan juga akan meningkat sebesar 0,10 . Hal tersebut dipengaruhi oleh fungsi produk wadiah yang bermanfaat bagi savety keuangan santri, selain itu bertambahnya simpanan akan mempengaruhi tingkat pembiayaan yang disalurkan sehingga akan berpengaruh terhadap naiknya tingkat kesejahteraan. Ketika simpanan pendidikan (PL2) meningkat sebesar 0,56, maka kesejahteraan juga meningkat sebesar 0,16. Hal ini dipengaruhi oleh santri yang ratarata sudah memanfaatkan produk simpanan pendidikan sebagai sarana pendukung untuk kebutuhan pendidikannya, sehingga apabila ada kebutuhan yang tidak terduga terkait fasilitas pendidikan maka santri dapat menggunakan simpanan tersebut, akhirnya kesejahteraan santri akan meningkat seiring tercukupinya kebutuhan mereka.

Ketika simpanan hari raya (PL3) mengalami kenaikan sebesar 0,80 maka kesejahteraan juga akan naik sebesar 0,23. Hal ini dipengaruhi oleh asumsi santri terhadap manfaat dari produk ini saat liburan hari raya telah tiba, salah satunya ialah dapat membantu membeli barangbarang untuk keperluan hari raya, sehingga dengan adanya produk ini kesejahteraan santri akan meningkat. Ketika pembiayaan mudharabah (PL4) mengalami kenaikan sebesar 0,26 maka tingkat kesejahteraan juga naik 0,74 diikuti oleh kenaikan produk 0,15 . Perolehan nilai ini dipengaruhi oleh a.jezsi santri yang setuju untuk mesmanfaatkan produk mudharabah, hal ini dapat ditunjukkan dengan pengaruhnya terhadap kenaikan tingkat kesejahteraan. Ketika PL5 (pembiayaan murabahah) mengalami kenaikan 0,279 maka kesejahteraan juga naik sebesar 0,79 diikuti oleh kenaikan produk sebesar 0,16 . Produk ini merupakan produk yang rata-rata disetujui oleh santri untuk dapat dijadikan fasilitas dalam jual-beli santri, hal tersebut dapat dilihat dari pengaruh adanya produk ini terhadap tingkat kesejahteraan santri yang memiliki perolehan nilai tertinggi, serta perolehan hasil kuesioner yang ratarata sudah setuju, sesuia dengan pernyataan dari Wulandari (2017: 73) yang menyatakan bahwa produk pembiayaan murabahah dapat dimanfaatkan oleh santri.

Ketika besaran margin (KL1) meningkat sebesar 0,9 maka produk juga naik 0,41, diikuti oleh kesejahteraan sebesar 0,20. Adanya peningkatan tersebut didasarkan pada besaran margin yang ditawarkan oleh pihak BMT, dengan jumlah margin yang dinilai sesuai dengan BMT pada umumnya, dengan nilai yang standar anggota akan berminat untuk menggunakan produk ini, sehingga penggunaan jumlah produk akan meningkat, akhirnya tingkat kesejahteraan santri juga akan meningkat karena adanya produk yang dapat menfasilitasi jual-beli mereka. Ketika besaran basil (KL2) meningkat 0,10 maka produk juga meningkat 0,49 , diikuti kesejahteraan sebesar 0,20 . Adanya peningkatan tersebut didasarkan pada naiknya besaran bagi hasil yang dipengaruhi oleh minat anggota dalam menggunakan produk mudharabah, dengan jumlah basil yang dinilai sesuai akan menyebabkan peningkatan terhadap penggunaan produk tersebut, akhirnya tingkat kesejahteraan juga akan mengalami 
peningkatan walaupun dalam tingkat yang belum signifikan.

Ketika waktu pemrosesan (KL3) meningkat 0,25 maka produk juga naik 0,11, diikuti kesejahteraan sebesar 0,58. Indikator ini dipengaruhi oleh kualitas layanan pemrosesan yang cepat dan tanggap dapat memicu tingkat penggunaan produk menjadi naik dikarenakan rasa puas yang dirasakan oleh santri (Sumenge, 2013: 76), walaupun tidak signifikan kenaikan tersebut juga berpengaruh terhadap tingkat kesejahteraan santri yang juga mengalami kenaikan. Ketika kemudahan pelayanan (KL4) meningkat 0,26 maka produk juga naik 0,12, diikuti kesejahteraan sebesar 0,6. Pada dasarnya pelayanan menjadi hal yang sangat menentukan minat santri terhadap penggunaan produk (Saidani \& Arifin, 2012: 21), ketika penggunaan produk meningkat maka kesejahteraan santripun meningkat dengan cukup signifikan. Ketika keaktifan anggota (KL5) meningkat 0,11 maka produk juga naik 0,51 , diikuti oleh kesejahteraan sebesar 0,25. Walaupun pengaruh tersebut belum dinyatakan signifikan, nyatanya keaktifan anggota menjadi Salah satu faktor utama dalam hal operasional hal tersebut dapat mempengaruhi tingkat penggunaan produk (Yuliani \& dkk, 2017: 111), pada akhirnya juga memicu adanya peningkatan pada tingkat kesejahteraan walaupun nilai tersebut belum signifikan. Selanjutnya melihat hubungan antar berdasarkan variabel kesejahteraan, akan digambarkan oleh tabel di bawah ini:

\section{Tabel 5}

Skor Hubungan Antar Indikator

KS1 KS2 KS3 KS4 KS5

$\begin{array}{llllll}\text { KS } & .068 & .078 & .068 & .098 & .057\end{array}$

\begin{tabular}{ccccc}
\hline KL .024 & .028 & .024 & .035 & .020 \\
\hline PL .051 & .059 .051 & .074 & .043
\end{tabular}

Ketika kesehatan (KS1) naik sebesar 0,68 maka kinerja juga naik sebesar 0,24, diikuti oleh kenaikan produk sebesar 0,51.
Berdasarkan pengaruh kenaikan di atas maka dapat disimpulkan bahwa produk kesehatan juga memiliki pengaruh terhadap peningkatan tingkat kinerja BMT walaupun tidak signifikan, hal ini terjadi karena BMT belum menerapkan produk yang memiliki fasilitas kesehatan, sehingga dapat diambil kesimpulan bahwa produk ini juga memiliki potensi untuk ditawarkan kepada santri berdasarkan hasil kuesioner yang rata-rata memberikan persetujuan. Ketika pendidikan (KS2) naik sebesar 0,078 maka kinerja juga naik 0,020 diikuti oleh produk sebesar 0,01. Pengaruh tersebut dipicu oleh penggunaan produk simpanan pendidikan yang rata-rata digunakan oleh santri, sehingga santri dapat secara langsung merasakan manfaatnya, sehingga dapat memicu naiknya tingkat kinerja BMT dan juga penggunaan produk lainnya.

Ketika keamanan (KS3) naik sebesar 0,68 maka kinerja juga naik 0,24 , diikuti kenaikan produk sebesar 0,51. Walaupun pengaruh tersebut tidak terlalu signifikan namun santri sudah merasa aman terhadap adanya BMT, rasa aman tersebut akan menyebabkan santri menjadi lebih loyal terhadap BMT sehingga akan mempengaruhi penggunaan produk, ditunjukkan dengan nilai KS3 yang mengalami kenaikan. Ketika KS4 (kebahagiaan) naik sebesar 0,98 maka kinerja juga naik 0,35, diikuti oleh kenaikan produk sebesar 0,74. Pengaruh ini dipicu oleh kesetujuan santri terkait adanya BMT yang memiliki manfaat terhadap keuangan mereka, perolehan tersebut nyatanya memberikan pengaruh terhadap kinerja dan juga penggunaan jumlah produk walaupun belum terlalu signifikan.

Ketika KS5 (IPM) naik sebesar 0,57 maka kinerja juga naik 0,20 , diikuti oleh kenaikan produk sebesar 0,43. Kenaikan indikator ini dipicu oleh adanya edukasi dan sosialisasi yang sudah diberikan oleh pihak BMT kepada santri, sehingga pengetahuan santri 
akan BMT menjadi lebih luas, selain itu adanya edukasi dan sosialisasi ini juga bermanfaat terhadap penggunaan jumlah produk di BMT. hal tersebut akan menyebabkan indikator kinerja BMT menjadi naik. Tabel 5 menjelaskan skor hubungan antar indikator, untuk melihat indikator yang paling dominan dapat dijelaskan oleh tabel sebagai berikut:

Tabel 6

Persentase Hubungan Masing-masing Indikator

\begin{tabular}{|c|c|c|}
\hline \multicolumn{2}{|c|}{ Indikator Estimate } & Dominan \\
\hline KL1 & $0.7 \%$ & \multirow{5}{*}{ KL4 } \\
\hline KL2 & $0.8 \%$ & \\
\hline KL3 & $33 \%$ & \\
\hline KL4 & $37 \%$ & \\
\hline KL5 & $12 \%$ & \\
\hline PL1 & $1.9 \%$ & \multirow{5}{*}{ PL5 } \\
\hline PL2 & $3.7 \%$ & \\
\hline PL3 & $10 \%$ & \\
\hline PL4 & $46 \%$ & \\
\hline PL5 & $48 \%$ & \\
\hline KS1 & $17 \%$ & \multirow{5}{*}{ KS4 } \\
\hline KS2 & $14 \%$ & \\
\hline KS3 & $14 \%$ & \\
\hline KS4 & $19 \%$ & \\
\hline KS5 & $13 \%$ & \\
\hline
\end{tabular}

Tabel 6 menggambarkan bahwa dari ketiga variabel laten yang digunakan yaitu kesejahteraan santri, produk LKMS dan kinerja LKMS, setelah dikolaborasikan indikator yang paling dominan pengaruhnya ialah PL5 (pembiayaan murabahah) sebesar $48 \%$, sehingga berdasarkan nilai tersebut dapat dikatakan bahwa pembiayaan murabahah merupakan indikator yang paling dapat menggambarkan kebutuhan produk pada BMT, sehingga BMT dianjurkan untuk mendesain produk ini, sedangkan signifikasi nilai keseluruhan indikator sebesar $100 \%$, sehingga dapat disimpulkan bahwa indikator-indikator tersebut sudah cukup menggambarkan kebutuhan produk yang ada pada BMT.

Kemudahan pelayanan (KL4) sebesar $37 \%$, berdasarkan nilai tersebut maka dapat dikatakan bahwa kemudahan pelayanan menjadi indikator yang paling menggambarkan kinerja pada BMT, sehingga BMT perlu meningkatkan layanan yang memberikan kemudahan pada santri agar dapat meningkatkan kinerjanya, sedangkan signifikasi keseluruhan indikator sebesar 98,3\% sehingga dapat disimpulkan bahwa terdapat indikator lain selain kelima indikator tersebut yang dapat menggambarkan kinerja pada BMT. kebahagiaan (KS4) sebesar 19,2\%, berdasarkan nilai tersebut maka dapat dikatakan bahwa kebahagiaan merupakan indikator yang paling menggambarkan kesejahteraan santri di pondok pesantren, sehingga BMT perlu mengoptimalkan perannya dan dapat membantu keuangan santri secara maksimal, sedangkan signifikasi keseluruhan indikator sebesar $77 \%$ sehingga dapat disimpulkan bahwa masih ada indikator lain selain lima indikator yang ada dalam penilitian ini yang dapat menggambarkan indikator kesejahteraan santri. Sedangkan untuk mengetahui hubungan antara konstruk dapat dilihat dari gambaran model jalur di bawah ini:

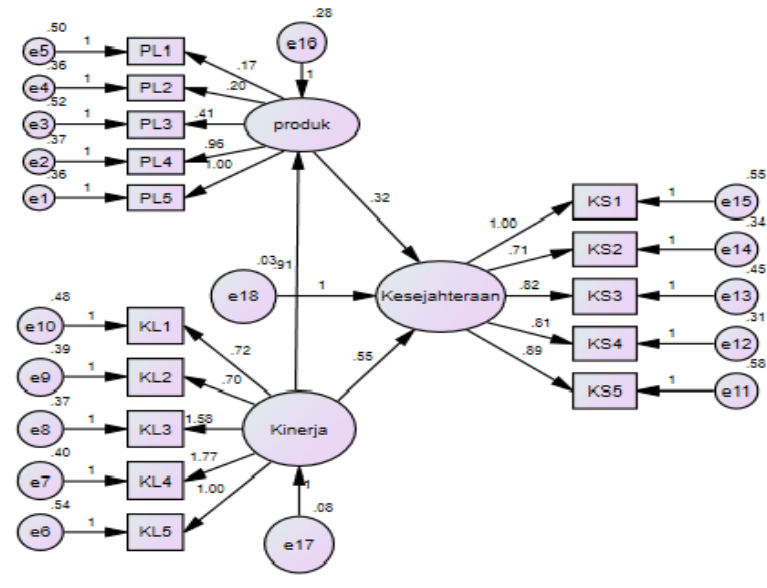

Gambar 1

Structural Model Kinerja LKMS dalam Meningkatkan kesejahteraan santri

Gambar 1 menjelaskan bahwa kemudahan pelayanan (KL4) dengan nilai $\mathrm{P}$ 
$0,00<0,05$ memiliki nilai estimate sebesar $(1,77)$, waktu pemrosesan (KL3) dengan nilai $\mathrm{P} 0,00<0,05$ memiliki nilai estimate sebesar (1,58), keaktifan anggota (KL5) dengan nilai $\mathrm{P} 0,00<0,05$ memiliki nilai estimate sebesar $(1,00)$, basil pembiayaan murabahah (KL1) dengan nilai P 0,01<0,05 memiliki nilai estimate sebesar 0,72 , basil pembiayaan mudharabah (KL2). Sehingga dapat dikatakan bahwa kemudahan pelayanan memiliki keterkaitan yang erat dengan indikator kinerja dan merupakan indikator yang paling menggambarkan indikator kinerja. Selain kemudahan layanan faktor yang paling penting dalam kinerja ialah waktu pemrosesan yang dinilai dapat mempengaruhi loyalitas santri sehingga akan berpengaruh terhadap indikator KL5 yakni keaktifan anggota.

Adapun pembiayaan murabahah (PL5) dengan skor nilai $P \quad 0,013 \geq 0,05$ memiliki nilai estimate sebesar $(0,96)$ sedangkan pembiayaan mudharabah (PL4) dengan nilai $P, 0,016 \geq 0,05$ memiliki nilai estimate $(1,00)$, simpanan hari raya (PL3) dengan nilai $P$ $0,00 \leq 0,05$ memiliki nilai estimate sebesar $(0,41)$, simpanan pendidikan (PL2) dengan nilai $P \quad 0,17 \geq 0,05$ memiliki nilai estimate sebesar $(0,20)$, simpanan wadiah (PL1) dengan nilai $P \quad 0,01 \leq 0,05$ memiliki nilai estimate sebesar $(0,17)$. Sehingga dapat dikatakan bahwa produk murabahah memiliki hubungan yang erat dengan variabel produk BMT walaupun tidak memiliki pengaruh yang sangat signifikan terhadap kinerja BMT.

Kesehatan (KS1) dengan nilai $P$ $0,00 \leq 0,05$ memiliki nilai estimate sebesar $(1,00)$,. KS5 (kebahagiaan) dengan nilai $\mathrm{P}$ $0,00 \leq 0,05$ memiliki nilai estimate sebesar $(0,89)$, KS3 (keamanan) dengan nilai $\mathrm{P}$ $0,00 \leq 0,05$ memiliki nilai estimate sebesar $(0,82), \mathrm{KS} 4$ (IPM) dengan nilai P $0,00 \leq 0,05$ memiliki nilai estimate sebesar $(0,81)$, KS2 (pendidikan) dengan nilai $\mathrm{P} \quad 0,00 \leq 0,05$ memiliki nilai estimate sebesar $(0,71)$. sehingga dapat dikatakan bahwa indikator kesehatan memiliki hubungan yang erat untuk menggambarkan kesejaheteraan yang ada di pondok pesantren, selain kesehatan indikator yang dinilai memiliki hubungan ialah indikator kebahagiaan.

Setelah melihat beberapa penjelasan di atas maka dapat disimpulkan bahwa KL1, KL2, KL3, KL4, KL5, PL1, PL2, PL3, PL4, PL5, KS1, KS2, KS3, KS4 dan KS5 dinilai dapat menggambarkan varibel laten berupa kinerja LKMS. Adapun variabel konstruk yang memiliki pengaruh ialah variabel kinerja terhadap produk yang sudah atau dapat ditawarkan oleh BMT dengan nilai estimate sebesar $0,91 \geq 0,05$, sehingga dapat dikatakan bahwa kinerja BMT dapat memberikan pengaruh terhadap produk baik dari segi kualitas maupun kuantitas, selain itu kinerja juga dinilai dapat mempengaruhi tingkat kesejahteraan santri yang ditunjukkan oleh nilai estimatenya sebesar $0,55 \geq 0,05$.

\section{Modifikasi Model Penelitian}

Santoso (2014:161) menyatakan bahwa modifikasi pada SEM ialah bertujuan untuk memperoleh Chi-Square yang lebih kecil. Berdasarkan data, berikut merupakan ggambaran model SEM setelah proses modifikasi. 
Tabel 7

Modifikasi Model Penelitian dan Data Eror

\begin{tabular}{|c|c|c|c|c|}
\hline & & & M.I. & Par Change \\
\hline $\mathrm{e} 12$ & $<-->$ & $\mathrm{e} 11$ & 4.400 & .067 \\
\hline e13 & $<-->$ & e11 & 6.189 & -.094 \\
\hline e14 & $<-->$ & e11 & 4.760 & -.072 \\
\hline e14 & $<-->$ & e13 & 4.070 & .059 \\
\hline e15 & $<-->$ & e11 & 4.280 & .087 \\
\hline e15 & $<-->$ & e12 & 10.251 & -.100 \\
\hline e10 & $<-->$ & e18 & 5.266 & .047 \\
\hline e10 & $<-->$ & e11 & 6.829 & .101 \\
\hline e10 & $<-->$ & e13 & 4.112 & .069 \\
\hline e9 & $<-->$ & e11 & 7.337 & .095 \\
\hline e9 & $<-->$ & e12 & 4.529 & -.055 \\
\hline e9 & $<-->$ & e10 & 10.893 & .103 \\
\hline e7 & $<-->$ & e11 & 9.533 & -.121 \\
\hline e7 & $<-->$ & e15 & 4.317 & -.080 \\
\hline e6 & $<-->$ & e15 & 6.865 & .106 \\
\hline e5 & $<-->$ & e17 & 15.124 & .066 \\
\hline e5 & $<-->$ & e14 & 6.884 & .078 \\
\hline e5 & $<-->$ & e10 & 5.590 & .082 \\
\hline e5 & $<-->$ & e6 & 7.753 & .104 \\
\hline e4 & $<-->$ & e17 & 6.409 & .037 \\
\hline e4 & $<-->$ & e10 & 5.466 & .069 \\
\hline e4 & $<-->$ & e5 & 9.587 & .093 \\
\hline e3 & $<-->$ & e11 & 4.990 & .089 \\
\hline e3 & $<-->$ & $\mathrm{e} 4$ & 5.190 & -.070 \\
\hline e2 & $<-->$ & e11 & 4.602 & .082 \\
\hline $\mathrm{e} 2$ & $<-->$ & e5 & 11.099 & -.116 \\
\hline e1 & $<-->$ & e14 & 4.619 & -.064 \\
\hline $\mathrm{e} 1$ & $<-->$ & $\mathrm{e} 10$ & 4.073 & -.070 \\
\hline
\end{tabular}

Tabel 7 merupakan hasil dari rekomendasi modifikasi oleh Amos 22, berdasarkan data tersebut ada beberapa variabel juga eror yang dapat diolah kembali dengan cara melakukan penggambaran ulang dengan arahan rekomendasi Amos 22.

Berikut merupakan penurunan yang diperoleh dari nilai Chi-Square:
Minimum was achieved
Chi-square $=229.639$
Degrees of freedom $=87$
Probability level $=.000$

Sumber: Data kuesioner diolah, 2018

\section{Gambar 2}

Nilai Chi-Square Model Structural
Ket: Angka Chi-Square masih sangat tinggi serta nilai Probility level $<0,05$

$$
\begin{array}{|l|}
\text { Minimum was achieved } \\
\text { Chi-square }=57.614 \\
\text { Degrees of freedom }=59 \\
\text { Probability level }=.527 \\
\multicolumn{1}{|c}{\text { Gambar } 3} \\
\text { Nilai Chi-Square Model Structural }
\end{array}
$$

Setelah melakukan modifikasi angka ChiSquare meningkat dari 22,9 menjadi 57,6. Hasil tersebut juga diikuti oleh penurunan Probability level dari 0,00 menjadi ,527.

Berikut merupakan gambar path diagram setelah dimodifikasi:

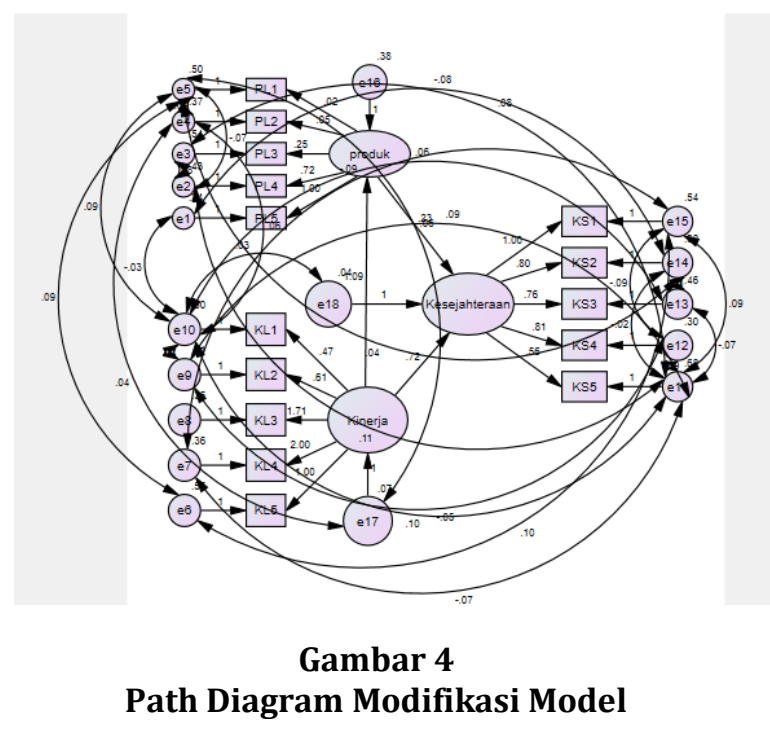

Gambar 3, 4 dan 5 menunjukkan bahwa model SEM sudah lebih fit dari sebelumnya sehingga pada uji modifikasi berikutnya akan mengalami penurunan di bawah 4, asumsi ini berdasarkan nilai SEM sebelum dimodifikasi ialah 22,9, menurun menjadi 57,6. Sehingga dapat disimpulkan bahwa model SEM sudah lebih fit setelah dilakukan modifikasi. 
Tabel 8

Evaluasi Model Goodness of Fit

\begin{tabular}{|c|c|c|c|c|}
\hline \multicolumn{5}{|c|}{ No Goodness of Fit Model Cut off Keterangan } \\
\hline (1) & $(2)$ & & 3) & ) \\
\hline 1 & $\begin{array}{l}\text { Chi-Square } \\
\text { value }\end{array}$ & $\mathrm{p}-$ & $\begin{array}{l}57.614 \\
\mathrm{P}= \\
(0,527)\end{array}$ & Good Fit \\
\hline 2 & RMSEA & & 0.00 & Good Fit \\
\hline 3 & RMR & & 0.25 & Good Fit \\
\hline 4 & NFI & & 0.49 & Good Fit \\
\hline 5 & CFI & & 1.00 & Good Fit \\
\hline 6 & IFI & & 1.00 & Good Fit \\
\hline 7 & RFI & & 0.78 & Good Fit \\
\hline 8 & Hoetler & & 98 & Good Fit \\
\hline 9 & GFI & & 0.96 & Good Fit \\
\hline 10 & AGFI & & 0.92 & Good Fit \\
\hline
\end{tabular}

Tabel 8 menunjukkan bahwa nilai GOF sudah sesuai dengan rata-rata perolehan nilai 0 sampai 1, hasil ini juga didukung oleh niali Degree of Freedom yang bernilai positif sebesar 59. Sedangkan hipotesis penilitian ini sendiri tida mengalami perubahan karena hasil sebelumnya juga menunjukkan semua hipotesis penelitian diterima, namun setelah dilakukan modifikasi nilai perolehan menjadi lebih tinggi dari sebelumnya. Seperti yang terdapat pada hasil nilai hitung maximum likelihood berikut ini:

Tabel 9

Evaluasi Pengujian Validitas dan Reliabilitas Variabel Pengukuran Modifikasi Model

\begin{tabular}{|c|c|c|c|c|c|}
\hline $\begin{array}{c}\text { Pengujian } \\
\text { Validitas } \\
\& \\
\text { Reliabilita } \\
\text { s }\end{array}$ & $\begin{array}{c}\text { Nilai } \\
\text { CR }\end{array}$ & $\begin{array}{c}\text { Nilai } \\
\text { Kritis }\end{array}$ & $\begin{array}{c}\text { Nilai } \\
\text { P }\end{array}$ & Ket & $\begin{array}{c}\text { Hipotesi } \\
\mathrm{s}\end{array}$ \\
\hline KL1 & 1.771 & $\geq 1.72$ & 0.07 & $\begin{array}{l}\text { Valid } \\
\text { Reliabel }\end{array}$ & \multirow{5}{*}{$\begin{array}{c}\text { H1 data } \\
\text { menduk } \\
\text { ung CR } \\
(2.742) \\
\geq 1.72 \\
\text { P } 0.01 \\
\leq 0.05\end{array}$} \\
\hline KL2 & 2.399 & $\geq 1.72$ & 0.01 & $\begin{array}{l}\text { Valid } \\
\text { Reliabel }\end{array}$ & \\
\hline KL 3 & 3.462 & $\geq 1.72$ & 0.01 & $\begin{array}{l}\text { Valid } \\
\text { Reliabel }\end{array}$ & \\
\hline KL4 & 3.592 & $\geq 1.72$ & 0,01 & $\begin{array}{l}\text { Valid } \\
\text { Reliabel }\end{array}$ & \\
\hline KL5 & 3.592 & $\geq 1.72$ & 0,01 & $\begin{array}{l}\text { Valid } \\
\text { Reliabel }\end{array}$ & \\
\hline PL1 & 0.176 & $\leq 1.72$ & 0.86 & $\begin{array}{l}\text { Tidak } \\
\text { Valid } \\
\text { tidak } \\
\text { Reliabel }\end{array}$ & $\begin{array}{l}\text { H2 data } \\
\text { menduk } \\
\text { ung } \mathrm{CR}\end{array}$ \\
\hline PL2 & 0.570 & $\leq 1.72$ & 0.59 & $\begin{array}{l}\text { Tidak } \\
\text { Valid }\end{array}$ & $\begin{array}{l}\geq 1.72 \\
\text { P } 0.00\end{array}$ \\
\hline
\end{tabular}

\begin{tabular}{|c|c|c|c|c|c|}
\hline & & & & $\begin{array}{l}\text { tidak } \\
\text { Reliabel }\end{array}$ & $\leq 0.05$ \\
\hline PL3 & 2.364 & $\geq 1.72$ & 0.01 & $\begin{array}{l}\text { Valid } \\
\text { Reliabel }\end{array}$ & \\
\hline PL4 & 4.632 & $\geq 1.72$ & 0.01 & $\begin{array}{l}\text { Valid } \\
\text { Reliabel }\end{array}$ & \\
\hline PL5 & 4.632 & $\geq 1.72$ & 0.01 & $\begin{array}{l}\text { Valid } \\
\text { Reliabel }\end{array}$ & \\
\hline KS1 & 3313 & $\geq 1.72$ & $\begin{array}{l}0.00 \\
0,00\end{array}$ & $\begin{array}{l}\text { Valid } \\
\text { Reliabel }\end{array}$ & $\begin{array}{l}\text { H3 data } \\
\text { menduk } \\
\text { ung CR } \\
(2.303) \\
\geq 1.72 \\
\text { P } 0.01 \\
\leq 0.05\end{array}$ \\
\hline KS2 & 3.313 & $\geq 1.72$ & 0.00 & $\begin{array}{l}\text { Valid } \\
\text { Reliabel }\end{array}$ & \\
\hline KS3 & 3.149 & $\geq 1.72$ & 0.00 & $\begin{array}{l}\text { Valid } \\
\text { Reliabel }\end{array}$ & \\
\hline KS4 & 3.410 & $\geq 1.72$ & 0.00 & $\begin{array}{l}\text { Valid } \\
\text { Reliabel }\end{array}$ & \\
\hline KS5 & 3.316 & $\geq 1.72$ & 0.02 & $\begin{array}{l}\text { Valid } \\
\text { Reliabel }\end{array}$ & \\
\hline
\end{tabular}

Berdasarkan tabel 9 maka dapat diketahui bahwa ada beberapa indikator yang tidak valid dan reliabel yaitu pada indikator PL 4 dan PL 5 yang memiliki perolehan nilai $\mathrm{CR} \leq 1,72$ serta $\mathrm{P} \geq 0,05$, hal tersebut dikarenakan produk belum diterapkan di BMT untuk saat ini sehingga tidak ada pengaruhnya terhadap kesejahteraan santri. Oleh karena itu dapat disimpulkan bahwa semua hipotesis diterima dengan perolehan nilai rata-rataCR $\geq 1,72$ dan $P \leq 0,05$.

Hasil kesimpulan ini tidak banyak mengalami perubahan hanya pada perolehan skor per indikator saja, berikut merupakan skor perolehan dari setiap indikator: 
Tabel 10

Evaluasi Hubungan Masing-masing indicator

\begin{tabular}{l|r|l|}
\hline Indikator & Estimate & Dominan \\
\hline PL1 & $1,7 \%$ & PL4 \\
PL2 & $5 \%$ & \\
PL3 & $22 \%$ & \\
PL4 & $59 \%$ & \\
PL5 & $8 \%$ & \\
\hline KL1 & $17 \%$ & KL5 \\
KL2 & $24 \%$ & \\
KL3 & $6 \%$ & \\
KL2 & $6,5 \%$ & \\
KL5 & $33 \%$ & \\
\hline KS1 & $4,3 \%$ & KS4 \\
KS2 & $4,4 \%$ & \\
KS3 & $3,6 \%$ & \\
KS4 & $4,6 \%$ & \\
KS5 & $4, \%$ & \\
\hline
\end{tabular}

Tabel 10 menggambarkan bahwa dari ketiga variabel laten yang digunakan yaitu kesejahteraan santri, produk LKMS dan kinerja LKMS, setelah dikolaborasikan indikator yang paling dominan pengaruhnya ialah PL4 (pembiayaan murabahah) sebesar $59, \%$, sehingga berdasarkan nilai tersebut dapat dikatakan bahwa pembiayaan murabahah merupakan indikator yang paling dapat menggambarkan kebutuhan produk pada BMT, sehingga BMT dianjurkan untuk mendesain produk ini, sedangkan signifikasi nilai keseluruhan indikator sebesar 73\%, sehingga dapat disimpulkan bahwa masih ada beberapa indikator yang belum terdapat dalam penelitian ini yang dinilai dapat menggambarkan kebutuhan produk yang ada pada BMT. Keaktifan anggota (KL5) sebesar 33\%, berdasarkan nilai tersebut maka dapat dikatakan bahwa Keaktifan anggota menjadi indikator yang paling menggambarkan kinerja pada BMT, sehingga BMT perlu meningkatkan layanan yang memberikan dapat meningkatkan stabilitas keaktifan santri dalam memanfaatkan produk yang ada di BMT, sedangkan signifikasi semua indikator sebesar $86,5 \%$ sehingga dapat disimpulkan bahwa terdapat indikator lain selain kelima indikator tersebut yang dapat menggambarkan kinerja pada BMT. kebahagiaan (KS4) sebesar 4,6\%, berdasarkan nilai tersebut maka dapat dikatakan bahwa kebahagiaan merupakan indikator yang paling menggambarkan kesejahteraan santri di pondok pesantren, sehingga BMT perlu mengoptimalkan perannya dan dapat membantu keuangan santri secara maksimal, sedangkan signifikasi keseluruhan indikator sebesar 20,9\% sehingga dapat disimpulkan bahwa masih ada indikator lain selain lima indikator yang ada dalam penilitian ini yang dapat menggambarkan indikator kesejahteraan santri.

\section{KESIMPULAN DAN IMPLIKASI}

Hasil penelitian ini menunjukkan bahwa besaran kinerja sangat berpengaruh terhadap produk yang ada di LKMS ditunjukkan dengan perolehan nilai konstruk sebesar 0.91 hal tersebut juga didukung oleh hasil analisis dengan nilai CR $2.612 \geq 1.72$ dan $P 0,00 \leq 0,05$. Adapun jumlah produk dinilai berpengaruh dalam meningkatkan kesejahteraan santri meski hal tersebut tidak terlalu signifikan ditunjukkan oleh perolehan nilai CR 2.486 dan P0,01 serta nilai konstruk sebesar 0.32, sedangkan pengaruh kinerja terhadap kesejahteraan juga dinilai cukup signifikan ditunjukkan dengan perolehan nilai CR 2.418 dan P0,01 serta perolehan nilai konstruk sebesar 0,55. Sehingga dapat disimpulkan bahwa semua hipotesis diterima, artinya semua variabel konstruk memiliki pengaruh. 
Selanjutnya demi mencapai hasil yang lebih optimal dalam pembahasan atau meminimalkan hasil penelitian yang bias terhadap topik atau tema yang sama, peneliti merekomendasikan kepada peneliti yang akan datang untuk membuat judul positif dan menambahkan beberapa faktor untuk di uji sesuai dengan perkembangan LKMS dan standar kesejahteraan dimasa yang akan datang.

\section{DAFTAR PUSTAKA}

Abidah, A. (2013). Pemahaman Respon Santri Pesantren Terhadap Perbankan Syariah di Ponorogo. Jurnal Justitia Islamica Vol 10, No 1, 109.

Alhifni, A., \& Huda, N. (2015). Kinerja LKMS Dalam Mendukung Kegiatan Ekonomi Rakyat Berbasis Pesantren (Studi Pondok Pesantren Darut Tauhid dan BMT Darut Tauhid . Jurnal Aplikasi Manajemen (JAM) Vol 13, No 4, 598.

Andriansyah, Y. (2009). Kinerja keuangan perbankan Syariah di Indonesia dan Kontribusinya bagi pembangunan Nasional. Jurnal La_Riba Vol. III, No 2 , 183.

Artana Yasa, I. O., \& Arka, S. (2015). Pengaruh Pertumbuhan Ekonomi dan Disparitas Pendapatan Antardaerah terhadap Kesejahteraan Masyarakat Provinsi Bali. Jurnal Ekonomi Kuantitatif Terapan Vol. 8, No. 1 ISSN : 2301-8698, 63-71.

Astuti, R. (2011). Penilaian Kesehatan Keuangan pada Kospin Jasa Syariah Pekalongan sebagai Lembaga Keuangan Mikro Syariah. Jurnal Penelitian Vol 8, No 1, 131-156.

Badan Pusat Statistik (BPS). (2017). Laporan Bulanan Data Sosial Ekonomi. Jakarta:

https://www.bps.go.id/website/pdf_p ublikasi/Laporan-Bulanan-DataSosial-Ekonomi-September-2017.pdf.
R, B., \& Mutlu, M. (2017). Financial Inclusion and Islamic Finance a Survey of Islamic Financial Literacy Index. Interational Journal of Islamic Economic and Finance Studies Vol 3, No 2 e-ISSN : 2149-8407, 36.

Masyitoh, N. D. (2014). Analisis Normatif Undang-Undang No. 1 Tahun 2013 Tentang Lembaga Keuangan Mikro (LKM) Atas Status Badan Hukum Dan Pengawasan Baitul Maal Wat Tamwil (BMT). Jurnal Conomica Vol V, Edisi 2, 17

Widyastuti, A. (2012). Analisis Hubungan antara Produktivitas Pekerja dan Tingkat Pendidikan Pekerja tehadap Kesejahteraan Keluarga di Jawa Tengah Tahun 2009. Economic Development Analysis Journal, 2

Prabowo, B. S. (2015). Pendidikan sebagai Investasi dan Konsumsi di MTS Negeri Godean. Jurnal El-Tarbawi Vol. VII, No. $2,177-194$.

Rahayu, N. S. (2015). Konribusi Lembaga Keuangan Mikro Syariah terhadap Pemberdayaan Perempuan (Studi Kasus BMT di Kabupaten Sleman Yogyakarta). Jurnal Inovasi dan Kewirausahaan, 165.

Retnaningsih, W. (2010). Analisis Manajemen Strategi terhadap Kinerja Usaha Kecil dan Dampaknya bagi Kesejahteraan Masyarakat Kecil di Mojokerto. Jurnal Aplikasi Manajemen Vol 8, No 4, 1065.

Pramono, S. E. (2014). Kineja Guru Sejarah: Studi Kausal pada Guru-Guru SMA di Kota Semarang. Jurnal Paramita Vol. 24, No. 1 ISSN: 0854-0039, 114-125.

Kuncoro, A., \& Husnurrosyidah . (2017). Kinerja Lembaga Keuangan Mikro Syariah dan Upaya untuk Mempertahankan Eksistensi Prilaku Masyarakat Pedesaan. Jurnal Analisa 
Akuntansi dan Perpajakan Vol 1, No 1, 63-74.

Luthfi, R. R. (2013). Peran Pariwisata terhadap Kesejahteraan Masyarakat di Sektor Lapangan Pekerjaan dan Perekonomian Tahun 2009-2013 (Studi Kasus: Kota Batu). Jurnal Ilmiah http://download.portalgaruda.org/art icle.php?article=Peran-Parawisata-

Terhadap-Kesejahteraan-Masyarakatdi-Sektor-Lapangan-dan-

Perekonomian-Tahun-2009-2013, 11

Hafidloh. (2015). Pengaruh Gaya Kepemimpinan Terhadap Kinerja Lembaga Keuangan Mikro Syariah. Jurnal JEBIS Vol 1, No 1. 1-20

R.A Y Prasetya, \& S. Herianingrum. (2016). Peranan Baitul Mal Wa Tamwil Meningkatkan Usaha Mikro Melalui Pembiayaan Mudharabah. Jurnal Syarikah Vol 2, No 2 P-ISSN 2442-4420 e-ISSN 228-6935, 253.

Mi'raj, D. A., \& H.R, M. N. (2015). Linkage Program Bank Syariah dengan BMT: Tinjauan Kritis bagi Pengembangan Sistem Keuangan yang Lebih Kaffah. Jurnal JESST Vol 2, No 10, 858.

Gina, W., \& Effendi, J. (2015). Program Pembiayaan Lembaga Keuangan Mikro Syariah (LKMS) dalam Peningkatan Kesejahteraan Pelaku Usaha Mikro (Studi Kasus BMT Baitul Karim Bekasi). Jurnal Al-Muzara'ah Vol. 3. No. 1 ISSN p; 2337-6333; e: 2355-4363, 3343.

Kara, M. (2013). Kontribusi Pembiayaan Perbankan Syariah terhadap Pengembangan Usaha Mikro, Kecil dan Menengah. Jurnal AHKAM Vol XIII, No 2, 316.

Muttaqin, A. (2012). Model Pembiayaan Baitul Mal Wa Tamwil dan Perannya dalam Keseahteraan Usaha Kecil
Menengah (UKM). Jurnal Humanity Vol. 7, No. 2 ISSN: 0216-8995, 35-45.

Bainus, A., \& dkk. (2015). Imaging Welfare Development the Issues and Challenges in West Papua, Indonesia. Presented on The 19th International Symposium of the International Consortium for Social Development 711 July, 2015 -SIM University Singapore (hal. 1-13). Bandung: http://repository.unpad.ac.id/22784/

Hamid, A. (2017). Pendidikan Karakter Berbasis Pesantren (Pelajar dan Santri dalam Era IT \& Cyber Culture). Surabaya: Imtiyaz.

Hidayat, M. (2016). Model Komunikasi Kyai dan Santri di Pesantren. Jurnal Komunikasi Aspikom, Vol. 2, No. 6, ISSN: 2548-8309, 385-395.

Hermawan, A. (2005). Penelitian Bisnis. Jakarta: PT. Gramedia.

Sodiq, A. (2015). Konsep Kesejahteraan dalam Islam. Jurnal Equiblirium Vol. 3, No. 2, 381-405.

Aryani, D., \& Rosinta, F. (2010). Pengaruh Kualitas Layanan Terhadap Kepuasan Pelanggan Dalam Membentuk Loyalitas Pelanggan. Bisnis \& Birokrasi Jurnal Ilmu Administrasi Dan Organisasi Vol. 17, No. 2 ISSN: 08543844, 114-126.

Saidani, B., \& Arifin, S. (2012). Pengaruh Kualitas Produk dan Kualitas Layanan terhadap Kepuasan Konsumen dan Minat Beli pada Ranch Market. Jurnal Riset Manajemen Sains Indonesia (JRMSI) Vol. 3, No. 1 ISSN 2301-8313, 122.

Yuliani , N., \& dkk. (2017). Faktor-faktor yang Mempengaruhi Sisa Hasil Usaha Koperasi Syariah Masjid di Bandung. 
Jurnal Keuangan dan Perbankan Vol 13, No. 2 ISSN: 2579-485X, 110-119.

Anggoro, W. J., \& Widhiarso, W. (2010). Konstruksi dan Identfiikasi Properti Psikonometris Instrumen Pengukuran Kebahagiaan Berbasis Pendekatan Indegenous Psychology studi Multitrait-Multimethod. Jurnal Psikologi

Luviana, Y. (2014). Pengaruh Variasi Produk dan Switching Barrier terhadap Loyalitas Pelanggan. Jakarta: Universitas Pendidikan Indonesia http://repository.upi.edu/16033/1/S _MBS_0803082_Chapter1.pdf. 